\title{
ABORDAGEM SOCIOAMBIENTAL NA EDUCAÇÃO PROFISSIONALIZANTE: UMA EXPERIÊNCIA VIA INVESTIGAÇÃO TEMÁTICA
}

\author{
Renata Gomes de Abreu Freitas ${ }^{1}$ \\ Rosane Moreira Silva de Meirelles ${ }^{2}$
}

\section{Resumo}

O presente estudo compreende parte da tese de doutorado da primeira autora, que tem como objetivo geral delinear caminhos metodológicos para a implementação da dimensão ambiental no ensino profissionalizante do Instituto Federal de Educação, Ciência e Tecnologia do Acre (IFAC) na perspectiva da Educação Ambiental Crítico-Transformadora. Nesses termos, o presente ensaio pretende apresentar o percurso investigativo na elaboração de um Programa de Conteúdos Críticos, via Abordagem Temática Freiriana, para fins de inserção da dimensão ambiental ao currículo do Ensino Médio Técnico. As etapas investigativas indicaram a ocorrência de situações-problemas presentes no contexto dos educandos e seus familiares, os quais, mediante atividades de problematização foram validadas como Temas Geradores. Estes, por sua vez, conduziram à estruturação de uma Rede Temática (Temas Geradores e Contratemas) a qual guiou a organização de um Programa de Conteúdos (Redução Temática), que, partindo do sistema socioeconômico vigente e do modelo de colonização/ocupação da Amazônia Sul-Ocidental, desvela as origens da desigualdade social, conflitos urbanos e a degradação ambiental. O conjunto dos conteúdos apresentados neste artigo articula-se entre si, mediado por uma proposta problematizadora que fomenta a reflexão e compreensão dos problemas socioambientais constituídos, historicamente, via expansão da fronteira desenvolvimentista na região.

Palavras-chave: Educação Ambiental; Investigação Temática; Paulo Freire; Educação Profissionalizante.

\section{SOCIO-ENVIRONMENTAL APPROACH IN PROFESSIONAL EDUCATION: AN EXPERIENCE THROUGH THE THEMATIC RESEARCH}

\begin{abstract}
The present study comprises part of the doctoral thesis of the first author, whose general objective is to outline methodological paths for the implementation of the environmental dimension in the professional education of the Federal Institute of Education, Science and Technology of Acre (IFAC) from the perspective of Environmental Education CriticalChanging. By these means, the present essay intends to present the investigative course in the elaboration of a Critical Content Program, through the Freire Thematic Approach, with the purpose of inserting the environmental dimension into the Technical High School curriculum. The investigative steps indicated the occurrence of situation vs. problems present in the context of the students and their families, which, through challenging activities, were validated as Generating Themes. These, however, led to the structuring of a Thematic Network (Generating Themes and Contrasts) which guided to the organization of a Content Program (Thematic Reduction), that starting from the current socioeconomic system and the colonization / occupation model of the South-Western Amazon, reveals the origins of social inequality, urban conflicts and environmental degradation. The set of contents articulate with each other, mediated by a challenging proposal that fosters the reflection and understanding of

\footnotetext{
${ }^{1}$ Programa em Ensino em Biociências e Saúde (IOC- Fiocruz), docente no Instituto Federal do Acre (IFAC).

${ }^{2}$ Programa em Ensino em Biociências e Saúde (IOC- Fiocruz), docente na Universidade do Estado do Rio de Janeiro (UERJ).
} 
socio-environmental problems historically constituted through the expansion of the developing border in the region.

Keywords: Environmental Education; Thematic Investigation; Paulo Freire; Professional Education

\section{ABORDAJEN SOCIOAMBIENTAL EM LA EDUCACIÓN PROFESIONAL: UMA EXPERIENCIA VÍA INVESTIGACIÓN TEMÁTICA}

\section{Resumen}

El presente estudio comprende parte de la tesis de doctorado de la primera autora, que tiene como objetivo general, delinear caminos metodológicos para la implementación de la dimensión ambiental en la enseñanza profesional del Instituto Federal de Educación, Ciencia y Tecnología de Acre (IFAC)bajo la perspectiva de la Educación Ambiental CríticaTransformadora. En éstos términos, el presente ensayo pretende presentar el recorrido investigativo en la elaboración de un Programa de Contenidos Críticos, por medio del abordajen temático freiriano, con el objetivo de insertar la dimensión ambiental en el currículo de la Enseñanza Media Técnica. Las etapas investigativas indicaron la ocurrencia de situaciones-problemas presentes en el contexto de los educandos y sus familiares, los cuales mediante actividades de problematización, fueron validadas como Temas Generadores. Estos a su vez, han conducido la estructuración de una Red Temática (Temas generadores y Contratemas) la cual orientó la organización de un Programa de Contenidos (Reducción Temática), que, partiendo del sistema socioeconómico vigente y del modelo de colonización/ocupación de la Amazonia Sur-Occidental, desvela los orígenes de la desigualdad social, los conflictos urbanos y la degradación ambiental. El conjunto de los contenidos se articulan entre sí, mediado por una propuesta problematizadora que fomenta la reflexión y comprensión de los problemas socioambientales constituidos históricamente, vía expansión de la frontera desarrollista en la región.

Palabras-clave: Educación ambiental; Investigación Temática; Paulo Freire; Educación Profesional.

\section{Introdução}

A Educação Ambiental, enquanto campo político da educação, tem crescido notadamente ao longo da sua trajetória, tanto no que se refere à sua inserção no contexto escolar (VEIGA, AMORIM e BLANCO, 2005; LOUREIRO, COSSÍO, 2007), quanto em termos de pesquisas ligadas à pós-graduação (CARVALHO, 2013). No entanto, em se tratando do contexto escolar, Tozoni-Reis e colaboradores $(2012,2015)$ avaliam que a inserção da educação ambiental, especialmente no ensino básico, tem se apresentado de maneira bastante frágil. Os autores ressaltam que são vários os determinantes dessa fragilidade, porém destacam as políticas de educação ambiental escolar que, muitas vezes, se reduzem a atividades secundárias e pontuais dissociadas de uma proposta curricular, além da incipiente formação continuada de professores frente a abordagem ambiental. Destacam também a sua condução por atores externos à escola, o que representa um risco já que suas ações podem ocorrer de modo divergente de uma proposta crítica, mas sim de legitimação da sociedade capitalista. Nesses termos, os autores, salientam a necessidade de políticas públicas eficazes para a sua inserção no currículo escolar, bem como de estudos e pesquisas acerca da educação ambiental escolar que possam colaborar para superação de sua fragilidade.

Loureiro (2004) aponta como fator limitador da educação ambiental a sua incipiente problematização teórico-prática. Nesse sentido, destaca o método dialético marxista como a 
melhor forma de pensar e transformar o mundo, pois este possibilita a ação e a reflexão sobre a complexidade das questões ambientais a partir da crítica ao modelo de produção capitalista.

Essa problematização teórico-prática enfatizada por Loureiro e compartilhada também por Lorenzetti e Delizoicov (2009) é essencial para que a educação ambiental não resulte no adestramento ambiental que discute Brügger (2004), ao se referir às práticas de educação ambiental, notadamente, biologizantes, conservacionistas e ilustrativas.

Estudo anterior de nosso grupo revelou que a educação ambiental praticada no Instituto Federal de Educação, Ciência e Tecnologia do Acre (IFAC), um dos últimos a ser implantado dentro da política de expansão da Rede Federal de Educação Profissionalizante (2010), ocorre apenas em algumas formações profissionais pertencentes ao Eixo Tecnológico Recursos Naturais e por meio de disciplinas específicas (FREITAS, PANZERI, MEIRELLES, 2015). A partir dos planos de ensino e sua aplicação, as autoras constaram que a práxis pedagógica dos professores responsáveis pelas disciplinas ambientais não apresenta referenciais teórico-metodológico definidos, apontando para uma tendência conservacionista/preservacionista na condução da abordagem ambiental em sala de aula. Pacheco (2012) ao discutir a importância da educação ambiental na Educação Profissional Técnica de Nível Médio, ressalta que é necessário formar os profissionais mediante o pensamento crítico com relação à questão ambiental para que, no exercício de suas atividades produtivas, busquem a preservação dos recursos naturais.

Com base no exposto, o presente estudo objetivou, elaborar um plano de conteúdos via abordagem temática Freiriana, que possibilite a inserção da temática ambiental na perceptiva da educação ambiental crítico-transformadora no ensino médio técnico, experiência ocorrida no Campus Rio Branco do IFAC.

Nesses termos, a presente pesquisa foi conduzida mediante duas questões de investigação: É possível obter temas geradores significativos com educandos/das da educação profissionalizante que possibilite a inserção da temática ambiental na perspectiva crítico-transformadora? Que papel têm os familiares dos educandos/as no processo de investigação e redução temática?

\section{Dinâmica de abordagem temática freiriana}

Em 1974, o educador brasileiro Paulo Freire lançou a obra Pedagogia do Oprimido a qual apresenta sua concepção de educação popular na perspectiva libertadora, destacando a metodologia de investigação e redução temática pensada para a educação dos excluídos na estrutura social (FREIRE, 2011). Segundo o autor, a abordagem temática pressupõe a dialogicidade como requisito metodológico da ação educativa. Porém, o autor salienta que o diálogo não deve ser um ato vazio, mas que possibilite a reflexão a respeito de situações do contexto dos/das educandos/das, levando estes a desvelarem, via mecanismos de problematização, suas próprias condições de existência e, uma vez conscientes, tornem-se cidadãos/cidadãs críticos com plena capacidade para agir e interferir em sua realidade social. Segundo o autor, essa tomada de decisão gera tensão entre pronúncia e denúncia do mundo; a expressão dos homens frente ao mundo, a práxis como ação reflexiva e intencional, visando transformar a maneira de agir (FREIRE, 2011).

Nesses termos, a metodologia guia-se pela investigação de situações presentes, existenciais, concretas e que reflitam o conjunto de aspirações dos sujeitos envolvidos. Tais situações, de forma geral, devem refletir contradições, conflitos sociais os quais serão admitidas como temas geradores e estes serão efetivamente adotados na organização do conteúdo programático, o que Freire conceitua como redução temática. Os temas geradores envolvem conhecimentos do senso comum dos educandos, opressões passivas, por vezes 
naturalizadas, as quais problematizadas deverão ser desconstruídas mediante a apreensão de conhecimentos sistematizados durante o ato pedagógico.

Delizoicov (1982) utilizou essa abordagem teórico-metodológica e a traspôs para a realidade escolar, especificamente, no contexto do ensino de ciências, a qual passou a ser disseminada como dinâmica de abordagem temática Freiriana (DELIZOICOV, 2008; DELIZOICOV, ANGOTTI, PERNANBUCO, 2011). A partir de Freire, Delizoicov (1982; 2008) a organizou em cinco etapas: 1) Levantamento preliminar da realidade local; 2) Análise das situações e escolha das codificações; 3) Diálogos descodificadores; 4) Redução temática; e 5) Trabalho em sala de aula. De maneira geral, as cinco etapas incluem o processo de investigação e redução temática, o que envolve a identificação de contradições sociais vivenciadas no universo dos educandos (temas geradores), os quais orientarão na composição do programa de conteúdos com vistas a abordagem dos referidos temas. Tal dinâmica se propõe desenvolver práticas educativas contextualizadas, problematizadoras e interdisciplinares fomentando, assim, processos de transformação social (DELIZOICOV, ANGOTTI e PERNANBUCO, 2011).

O estudo de Silva (2004) intitulado: A construção do currículo na perspectiva popular, o qual apresenta como objeto a organização da práxis curricular interdisciplinar via temas geradores com fins de superar as práticas pedagógicas convencionais, gerou enormes contribuições para a abordagem temática também no ensino de ciências, tendo aprofundado o processo de redução temática, etapa que coincide com a construção do programa curricular, a partir dos temas geradores obtidos com o processo de investigação (TORRES, 2010; DEMARTINI, SILVA, 2013).

O referido autor organizou a práxis curricular via tema gerador em cinco momentos: IDesvelamento do real pedagógico a partir das necessidades imanentes da prática; II - Resgate das falas significativas constituindo sentido à prática: elegendo temas/contratemas geradores; III - Contextualização e percurso do diálogo entre falas e concepções da realidade local: rede temática e questões geradoras; IV-Planejamento e organização pedagógica da prática crítica; V - Reorganização coletiva da escola a partir do fazer pedagógico.

$\mathrm{Na}$ análise de tal referencial, Silva (2004) sistematizou, a partir da adoção de falas significativas, chegando à construção de currículos transformadores da realidade social. Os momentos de II a IV de sua organização curricular via temas geradores correlacionam-se às cinco etapas de Delizoicov (1982; 2008). Desse modo, a dinâmica organizada por Silva (2004), para fins de sistematização da práxis transformadora, veio para dinamizar mais ainda a abordagem temática freiriana (TORRES, 2010).

A Pedagogia Freiriana, de forma geral, nasce na e para a educação popular, sendo adotada como referencial formativo para inúmeros grupos representativos do movimento social brasileiro e também em outros países da América Latina. Em decorrência da Educação Ambiental ter sido concebida no âmbito do movimento ambientalista, é notável a presença de Paulo Freire em sua trajetória (LAYRARGUES, 2014). No entanto, alguns autores apresentam um panorama de como discursos e práticas Freirianas são apropriadas no campo social da Educação Ambiental e revelam que, embora Freire seja adotado como referencial teórico-metodológico em propostas curriculares e programas públicos de educação ambiental, bem como em estudos acadêmicos, observam-se indícios de uma incoerência entre o que se quer fazer e o que se faz com o pensamento Freiriano na educação ambiental, o que pode acontecer em virtude da sua metodologia não ser apropriada fielmente, conforme seus pressupostos (TORRES, DELIZOICOV, 2009; TORRES, 2010).

\section{Caminho metodológico}


A presente pesquisa classifica-se como pesquisa-ação (THIOLLENT, 2011), realizada por uma professora-pesquisadora e compartilhada por alunos/as do ensino médio integrado à formação técnica do Campus Rio Branco (IFAC), localizada na capital acreana. Para a obtenção de temas geradores e a possibilidade de integrá-los a um programa de ensino com vista à inserção da abordagem ambiental, realizaram-se as quatro fases sistematizadas por Delizoicov (1982; 2008), bem como lançou-se mão dos momentos II a IV da dinâmica de Silva (2004) referente à construção do currículo na perceptiva popular crítica e práticas contextualizadas. A pesquisa foi autorizada pelo Comitê de Ética em Pesquisas da Fundação Oswaldo Cruz sob o Parecer 775.767 CAE: 31891214.1.00005248.

Abaixo constam os objetivos de cada uma das cinco fases do processo de investigação e redução temática, segundo os autores citados acima, seguidos da descrição dos procedimentos que foram adotados para sua realização.

Etapa 1 - Levantamento preliminar: consiste em reconhecer o contexto social, histórico, econômico e cultural em que vive o estudante. Neste estudo, essa etapa foi alcançada por meio de três procedimentos de coleta de dados: A) Questionário com os estudantes; B) Atividade clicando nossa realidade socioambiental; e C) Entrevistas com servidores da unidade de ensino e familiares.

O procedimento A foi realizado com todos os estudantes do Ensino Médio técnico do Campus Rio Branco; os demais procedimentos foram realizados com estudantes do $2^{\circ}$ e $3^{\circ}$ ano, em virtude da possibilidade da professora-pesquisadora poder desenvolver as demais etapas da investigação e redução temática. Com o questionário obtiveram-se dados a respeito de interesses e experiências desses estudantes com a instituição, aspectos relacionados ao papel da educação na formação cidadã, da educação ambiental, da formação profissionalizante, aspectos referentes ao seu local de moradia e convivência, dentre outras questões que possibilitaram expressar suas realidades sociais.

No procedimento B, propôs-se aos estudantes uma atividade intitulada: Clicando minha realidade socioambiental. A ideia era que observassem e registrassem, com câmera fotográfica ou aparelhos celulares, situações que representassem a realidade vivida, incluindo aspectos sociais, econômicos, políticos, culturais e ambientais. As imagens foram apresentadas, pelos próprios estudantes, em mídia digital (arquivo em modelo de apresentação Power Point - Microsoft Office) por meio das quais foram relatadas as principais questões encontradas, bem como os fatores que as geraram. As entrevistas (procedimento C) visaram levantar situações complementares, assim com servidores da instituição obtiveram-se dados com relação à situação socioeconômica das famílias dos alunos, permanência, políticas de assistência estudantil, entre outros. Já os familiares, entrevistados em suas próprias moradias, oportunidade em que foi observado também o ambiente de vivência dos estudantes, atuaram como coparticipantes do processo de investigação temática, uma vez que poderiam esclarecer outras situações que os estudantes deixaram de mencionar.

Etapa 2 - Análise das situações e escolha das codificações: nessa etapa foram resgatadas as informações obtidas no levantamento preliminar a fim de identificar situaçõeslimites presente no contexto dos estudantes. Aqui, adotou-se o momento II de Silva (2004), no qual foram resgatadas falas significativas que expressaram problemas, contradições e visões de mundo dos participantes.

Etapa 3 - Diálogos descodificadores: essa etapa envolveu problematização das situações que foram explicitadas nas falas significativas, a fim de validá-las como temas geradores. Para tanto, estabeleceram-se diálogos com os estudantes por meio da realização de atividades problematizadoras. 
Etapa 4 - Redução temática: Trata-se da elaboração do programa curricular onde foram identificados os conhecimentos necessários para o entendimento dos temas geradores. Segundo as orientações originais, essa etapa deve ser realizada por equipe multidisciplinar, porém, no caso dessa pesquisa, a professora-pesquisadora conduziu todo o processo buscando integração entre conteúdos das ciências biológicas e humanas, tais como sociologia, história e principalmente geografia, dado o envolvimento pleno da mesma nesta área.

Etapa 5 - Trabalho em sala de aula: Trata-se da ação pedagógica, onde foi feita a devolução dos temas geradores aos alunos, sistematizado e ampliado, o que demandou a organização de materiais didáticos. Neste estudo, limitamos a apresentar os conteúdos, as abordagens e estratégias utilizadas com vista ao diálogo na perspectiva dos temas que emergiram do processo da investigação temática.

\section{Resultados e discussão}

\subsection{Quanto à realidade dos estudantes}

Os/as estudantes participantes da pesquisa $(n=123)$ pertencem a classes sociais econômicas heterogêneas, variando de média para baixa renda, observando o contexto do estado do Acre. Em sua maioria, concluíram o ensino fundamental em escolas públicas, com raras exceções, de estudantes oriundos de escolas privadas. Constatou-se que o interesse pela escola profissionalizante foi motivado, primeiramente, por ser do sistema federal $(71 \%)$, considerando-a de melhor qualidade para fins do Exame Nacional de Ensino Médio (ENEM) e segundo pela possibilidade de formação técnica integrada (29\%). Esse último grupo (29\%), declarou interesse em seguir carreira no curso profissionalizante a qual estão vinculados. Os demais participantes $(71 \%)$ vislumbram outras carreiras como medicina, direito e engenharias.

Estudantes enquadrados na categoria de baixa renda são atendidos com a política de auxílio permanência da instituição. No entanto, a taxa de evasão e reprovação é alta, em virtude de adaptação e acompanhamento da dinâmica de escola técnica. Foi possível constatar que um número significativo das famílias migrou da zona rural ou de outras cidades do interior do estado para a capital Rio Branco, motivados pela busca de melhores condições de vida, o que se relaciona com o forte êxodo rural desde a década de 60 , com o advento da expansão da fronteira agropecuária para a região (SILVA, 2003).

Os bairros em que residem, em sua maioria foram formados por invasão e apresentam deficiência em termos de infraestrutura e lazer. Foi constatada a ausência ou pouca pavimentação das ruas, frágil saneamento básico, havendo o descarte de águas servidas e resíduos sólidos diretamente em cursos d'água. Em termos de atendimento à saúde, relataram se sentirem parcialmente contemplados. Um dos problemas mais relevantes refere-se à insegurança vivenciada em função da violência, geralmente, correlacionado ao tráfico de entorpecentes, assim como questões relacionadas à renda e oportunidades de trabalho.

\subsection{Situações significativas identificadas}

Ao término da etapa de levantamento preliminar, analisaram-se as situações obtidas, resultando na seleção de 10 falas que exprimiam situações problemas, geradoras de tensão e conflitos, indicando possibilidades de tornarem-se temas geradores. Tais falas, como podem ser observadas, não retratam apenas uma situação específica, mas um conjunto de questões com possiblidades de se correlacionarem, o que poderia favorecer a inserção da dimensão ambiental crítico-transformadora. 
Fala 1. Estudar vale tudo, hoje em dia só trabalha quem sabe de alguma coisa ou tem conhecimento. Somente por meio da educação, estudando é que teremos mais pessoas boas e menos vagabundos (aluno);

Fala 2. A educação ambiental, seria no ponto de vista, um modo de aprender a enxergar a natureza como algo importante, ter consciência da grandiosidade da natureza, preservá-la (aluno);

Fala 3. ...todo dia é notícia de casa arrombada, roubo de carro até com pessoas feitas reféns. E também tem muitas mortes, violência, quase sempre envolvendo tráfico de drogas. É preciso mais segurança na cidade inteira, só assim é possível para combater a criminalidade (mãe de aluno);

Fala 4. ...Lá em casa mesmo sabemos quem entrou, mas tem que ficar calado né, não pode chamar a polícia porque eles ficam preso uma semana e depois vem querer colocar fogo na casa da gente... (mãe de aluno);

Fala 5. Antes para eu ir para escola usava sacola nos pés por conta da lama. Aí veio o programa ruas do povo que deu uma melhoradinha, mas quando dar uma chuva o asfalto sai até nos pés (aluno);

Fala 6. O Matheus... a família dele é de área que alaga todo ano... a mãe dele fez cadastro e até hoje não recebeu a casa do governo (aluno);

Fala 7. A cidade é cheia de esgotos a céu aberto, e isso pode ocasionar doenças como a dengue, o zika e outros. O igarapé da maternidade foi revitalizado toda área, que agora é o Parque da Maternidade, mas continua aberto, deveriam ter tampado todo ele para impedir a saída do cheiro ruim, que é horrível (aluno);

Fala 8. Eu queria muito ter um celular que tivesse WhatsApp, assim dava para falar com o pessoal, fazer pesquisas da aula, mas meus pais não podem comprar. Eu acho que é isso que é triste assim para mim. Meu pai tá desempregado já vai fazer um ano, ele já tá é pra desistir de tanto que procura e não dá, pois só a minha mãe que trabalha (aluno);

Fala 9. O que me faz infeliz...é assim... que não tô trabalhando já tem mais de ano e a forma que tenho de ajudar é levando ela de moto para o trabalho (a esposa). Aí também levo e pego os meninos na escola. Mas, para um homem é chato...é difícil ver só a mulher botando o que comer dentro de casa (pai de aluno);

Fala 10. Trabalho de doméstica, mas com essa dificuldade...aí da crise a patroa disse que não dava mais para pagar o salário (salário mínimo), falou que só dava pra pagar só metade. Não tenho o que fazer né, preciso desse trabalho... é ir levando já que não tem outro jeito...é difícil, porque os meninos às vezes pedem as coisas e a gente não pode dar ... eu falo não dar, não dar... é uma vida bem regrada......nem eu nem o pai deles tem estudo (mãe de aluno).

As falas aqui relacionadas contemplam vozes de alunos e de familiares que, em sua maioria, expressam suas visões com relação às suas realidades, revelando, assim, conflitos e contradições vivenciados em seus contextos sociais conforme os parâmetros propostos por Silva (2004). O autor salienta que é um momento importante, pois permite a contextualização e a participação coletiva; neste caso da professora-pesquisadora, alunos e familiares, estabelecendo uma relação de igualdade nas intenções educativas na proposta de transformação social.

\subsection{Problematização das falas significativas}

A validação das falas significativas em temas geradores foi realizada por meio de atividades de problematização apresentadas por códigos (imagens). Em virtude de as falas contemplarem diferentes questões correlacionadas, como mencionado anteriormente, 
organizaram-se estas em quatro eixos: educação, violência/criminalidade, infraestrutura urbana/habitação/meio ambiente e emprego e renda, propondo-se, assim, três atividades de problematização.

A primeira atividade consistiu em problematizar a fala:

Estudar vale tudo, hoje em dia só trabalha quem sabe de alguma coisa ou tem conhecimento. Somente por meio da educação, estudando é que teremos mais pessoas boas e menos vagabundos (fala de aluno).

Consideramos essa frase significativa, pois ela envolve questões de educação e trabalho e, mesmo não tão explícito, sobre violência e criminalidade. Consideramos limiteexplicativo o fato de considerarem a educação apenas como meio para projeção social e não como elemento de transformação social, o que fica claro quando buscam a escola federal como possibilidade de acessarem carreiras promissoras, o que poderia ser uma forma de romper individualmente com algumas condições de opressão, mas não promovendo sua transformação mais ampla e mais profunda.

Para problematizar essa questão e compreender o que pensam os estudantes sobre o papel da educação na formação cidadã, utilizamos duas imagens que refletiam sobre a escolha pela educação ou criminalidade (figura 1).

Figura 1: Imagens utilizadas na atividade de problematização I
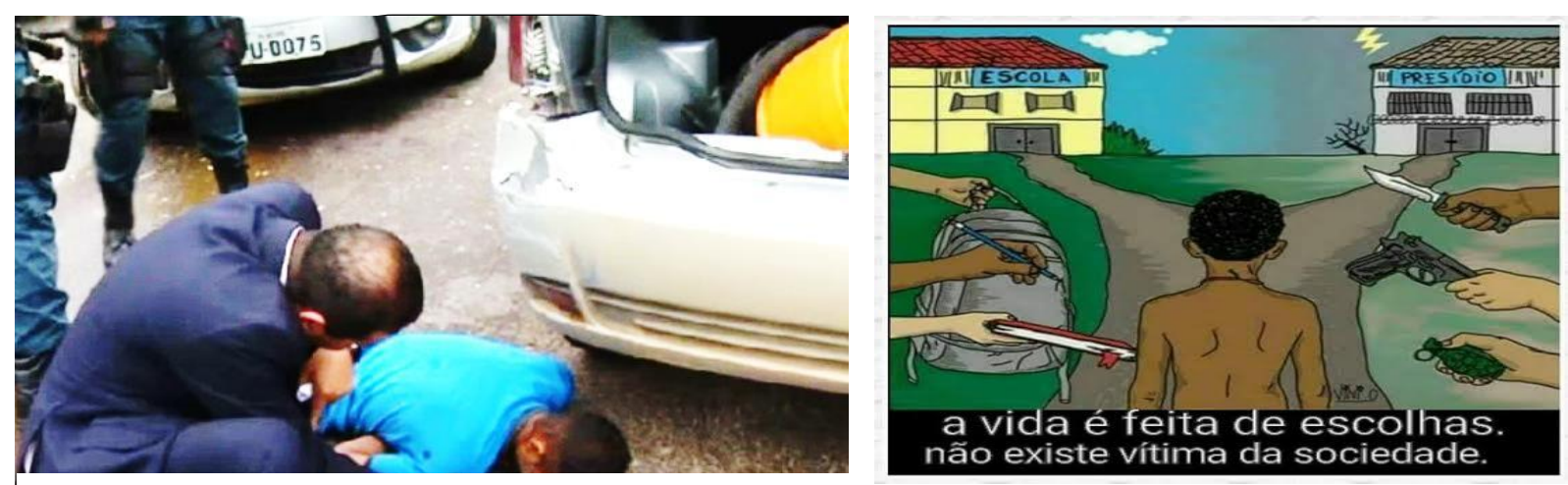

"Polícia prende homem acusado de cometer assaltos à mão armada, tanto de pessoas na rua quanto em residências"

A primeira situação apresenta uma matéria jornalística em que um jovem é apreendido por cometer crimes de furtos à mão armada e violação de residências. A segunda situação trata-se de uma ilustração que foi selecionada a partir de discussões nas redes sociais e costuma dividir opiniões, uma vez que polemiza o fato de o crime ser uma escolha individual, não considerando os fatores socioambientais.

Para estabelecer a roda dialógica proposta por Freire, foram apresentadas algumas questões a fim de possibilitar a discussão das situações pelos estudantes:

- As pessoas que nascem pobres não têm muita saída e acabam indo compor o exército da criminalidade;

- As pessoas que tiveram a oportunidade de estudar, que são pessoas de bem, são vítimas da violência.

Parte dos/das estudantes concorda que as pessoas de baixa renda encontram no crime uma forma mais fácil de ganhar dinheiro e, como a maioria quer ser possuidora de bens e objetos, acabam sendo atraídos para o mundo do crime. Essa posição correlaciona-se as falas 8 e 10. 
Eu queria muito ter um celular que tivesse WhatsApp, assim dava para falar com o pessoal, fazer pesquisas da aula, mas meus pais não podem comprar. Eu acho que é isso que é triste assim para mim. Meu pai tá desempregado já vai fazer um ano, ele já tá é pra desistir de tanto que procura e não dá, pois só a minha mãe que trabalha (aluno).

Trabalho de doméstica, mas com essa dificuldade...aí da crise a patroa disse que não dava mais para pagar o salário (salário mínimo), falou que só dava pra pagar só metade. Não tenho o que fazer né, preciso desse trabalho... é ir levando já que não tem outro jeito ... é difícil, porque os meninos às vezes pedem as coisas e a gente não pode dar...eu falo não dar, não dar... é uma vida bem regrada...nem eu nem o pai deles tem estudo (mãe de aluno).

Por outro lado, consideram que não se trata de uma regra, uma vez que pessoas de baixas condições financeiras conseguem estudar e vivem de seu trabalho, assim como jovens que mesmo tendo nascido em famílias de condições financeiras razoáveis, ainda assim, optam pelo crime.

Sobre a segunda situação (apresentada na figura 1 acima), consideraram que as oportunidades são colocadas a todos, mas nem todos procuram os caminhos que os levem a serem cidadãos de bem. Com isso, aqueles que vivem do trabalho honesto acabam sendo vítimas dos que escolheram o modo mais fácil de sobreviver. Por outro lado, foram apresentados argumentos que mostraram que o meio, muitas vezes, leva os jovens a entrarem para o mundo dos vícios e do crime na tentativa de se sentirem aceitos em grupos ou gangues do bairro, ou mesmo na escola. Assim, possuir um objeto de tecnologia avançada (como um aparelho celular) poderia também ser uma forma de ser aceito em ambiente escolar. Ainda sobre esta ilustração, os estudantes discutiram que as pessoas têm livre arbítrio para definir suas escolhas, seja pelo crime ou por formas dignas de sobrevivência. A sociedade em parte impõe suas regras, mas no geral, as pessoas que optam pelo crime são atraídas pelo modo mais fácil e geralmente não se dão conta de que o caminho tomado é degradante.

Em momento oportuno da roda dialógica, indagamos aos alunos sobre que medidas poderiam ser adotadas para conter a criminalidade que expõe a população à violência. Os que se posicionaram apontaram que são necessárias medidas de intensificação de policiamento nas ruas e maior austeridade nas leis de apreensão daqueles que comentem os crimes, não sendo mencionados, em nenhum momento, aspectos relacionados a políticas públicas sociais de integração, profissionalização das pessoas de baixa renda.

A segunda atividade de problematização realizada (denominada problematização II) envolveu os eixos infraestrutura urbana/habitação/meio ambiente e violência, sendo, para tanto, exposto um mosaico com algumas das imagens trazidas pelos alunos como representação da sua realidade socioambiental (procedimento B- Clicando nossa realidade socioambiental). $\mathrm{O}$ conjunto das imagens retrata uma realidade marcada pela frágil infraestrutura dos locais de moradia, má disposição de resíduos sólidos, esgotamento sanitário a céu aberto ou canalizado diretamente para cursos d'água, habitações em lugares inapropriados (margens e várzeas de rios e igarapés) e imagem que ilustrava o uso de drogas ilícitas, o qual geralmente associa-se a situações de crime e expõe a população à violência (Figura 2). 
Figura 2: Imagens trazidas pelos alunos para a atividade de problematização II

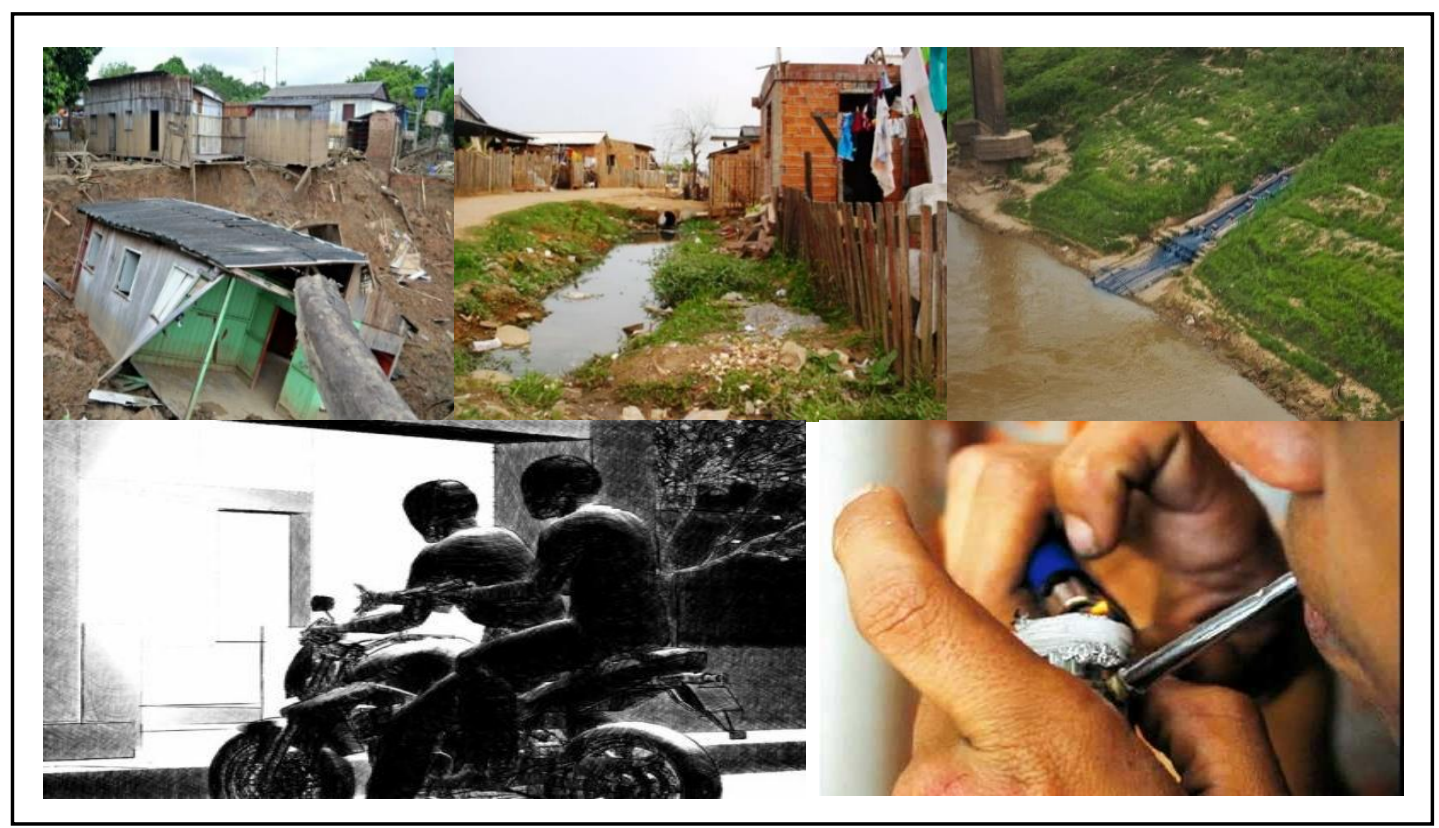

A proposta, com o uso desta atividade foi verificar se os/as estudantes percebiam interrelação entre as situações ilustradas que envolvem questões sociais e de gestão do ambiente. Para tanto, foram apresentadas duas principais questões para propiciar o diálogo:

- O mosaico de imagens, aqui apresentado, retrata que situação?

- Que relações podem ser estabelecidas entre os aspectos registrados nas imagens?

De forma quase unânime, os/as alunos responderam à primeira questão, afirmando se tratar de situações de desigualdade social, questões ambientais e falta de gestão por parte dos governantes, ao se referir as questões de infraestrutura, saneamento e habitação:

O comércio das drogas geralmente está mais presente nos bairros periféricos, onde muitas vezes a polícia não tem como ir, devido as ruas não ter asfalto, ou serem becos..... Se tem venda de drogas também tem os assaltos, os roubos por perto...também nos bairros mais pobres falta o saneamento básico, que gera a poluição do rio com lixos e os esgotos (roda dialógica).

Um dos problemas da nossa cidade são as pessoas que moram na beira do rio. Elas são carentes e não têm para onde ir...aí na época da alagação perdem todas as suas coisas tanto devido a água como por roubos. Os marginais ainda se aproveitam da situação (roda dialógica).

As falas coletivas acima, que surgiram nesse momento de problematização, associamse a uma das falas estabelecidas como significativa (fala 6) que trata sobre habitação: $O$ Matheus, a família dele é de área que alaga todo ano... a mãe dele fez cadastro e até hoje não recebeu a casa do governo (aluno).

As falas envolvem questões de habitação em ambientes inapropriados, principalmente às margens dos rios, favorecendo uma população em estado de vulnerabilidade, em virtude das chamadas "alagações" que ocorrem quando os níveis das águas, em período de inverno 
amazônico, se elevam e atingem as residências, mas também em virtude da baixa infraestrutura e precário saneamento que implicam atividades criminosas e a poluição.

Observamos que as duas falas registradas, contemplam também a segunda questão proposta, uma vez que os/as estudantes fazem relações entre algumas questões, a exemplo do fato das habitações em lugares inapropriados o que sem infraestrutura poderiam favorecer o tráfico de drogas e outras atividades criminosas. Além disso, fazem relação sobre a ausência de saneamento básico com a poluição dos rios e igarapés pelo descarte de lixo e águas servidas, o que está diretamente relacionado com o ambiente de moradia e a baixa infraestrutura presente.

A partir desta associação fizemos mais algumas indagações em busca dos limitesexplicativos:

1. A poluição dos rios e igarapés que cortam a cidade é cometida pelos moradores que se situam a suas margens?

2. Uma das maneiras mais eficazes para resolver esse problema seria passar a autuar e multar os moradores?

3. Caso concorde, o que acha que deveria ser feito como providências para resolver o problema da poluição dos igarapés e rios que cortam a cidade?

Sobre a primeira questão, uma pequena parte dos/das estudantes mencionou que o governo tem participação, tendo em vista a ausência de tratamento de esgoto, coleta do lixo, principalmente, os de entulho. Por outro lado, uma quantidade de alunos/as considerou que sejam os próprios moradores os principais responsáveis pela poluição dos rios, uma vez que descartam móveis, lixos domésticos e esgotos no leito dos igarapés e rios.

....sim, os moradores são os responsáveis pela poluição dos igarapés e rios e deveria ter punição para quem polui (roda dialógica).

Quanto à segunda questão, embora a frase acima faça menção à punição, houve posições contrárias, considerando que não tem como resolver a questão somente penalizando, uma vez que o saneamento básico é insuficiente na maioria das faixas periféricas da cidade. Nesse caso, respondendo à questão 3, os estudantes indicaram que obras de infraestrutura urbana e eficiência no saneamento básico seriam medidas iniciais para resolver a questão.

Observamos que, com os processos de contextualização da sua realidade, os/as estudantes perceberam, embora de forma simplificada, as questões de forma integrada, o que requer aprofundamento quanto aos fatores de conjuntura maior que geram tais problemas.

A terceira atividade de problematização (denominada problematização III) envolveu os eixos trabalho, emprego e renda. Informações obtidas no levantamento preliminar permitiram observar que existe um enfretamento relacionado à baixa renda, desemprego e dificuldades de atendimento às necessidades básicas, como pode ser observado nas falas a seguir, registradas por uma das famílias (falas 9 e 10):

O que me faz infeliz...é assim.... que não tô trabalhando já tem mais de ano e a forma que tenho de ajudar é levando ela de moto para o trabalho (a esposa). Aí também levo e pego os meninos na escola. Mas, para um homem é chato...é difícil ver só a mulher botando o que comer dentro de casa (pai de aluno).

Trabalho de doméstica, mas com essa dificuldade...aí da crise a patroa disse que não dava mais para pagar o salário (salário mínimo), falou que só dava pra pagar só metade. Não tenho o que fazer né, preciso desse trabalho... é ir levando já que não tem outro jeito ... é difícil, porque os meninos às vezes pedem as coisas e a gente não pode dar...eu falo não dar, não dar... é uma vida bem regrada...nem eu nem o pai deles tem estudo (mãe de aluno). 
Conforme se constatou na primeira frase, o desemprego é uma situação-limite, pois desqualifica o pai como provedor da família. Por outro lado, há uma situação de naturalização da condição, portanto, opressora quando a mãe (segunda fala) se submete a receber um salário inferior e continuar fazendo o mesmo serviço, justificando tal condição por falta de opção de trabalho associado à falta de instrução.

Tendo em vista já estarmos cientes da relação desses problemas com a população expropriada do campo em detrimento das políticas de ocupação e desenvolvimento definidas para a região do estado do Acre, foram apresentadas aos estudantes duas situações que ilustravam a migração do campo para cidade, onde se acredita haver melhores condições de sobrevivência, mas enfrenta uma série de situações nesse novo espaço, como ocupar as áreas mais desvalorizadas da cidade, que são as regiões de ocupações inapropriadas, além de viverem, geralmente, do emprego informal e subemprego. Por serem moradores de regiões sem infraestrutura e segurança, os filhos destes estão mais expostos à criminalidade, entre outras questões que foram acrescentadas pelo professor (Figura 3).

Figura 3: Situações-problema que compuseram a atividade de problematização III

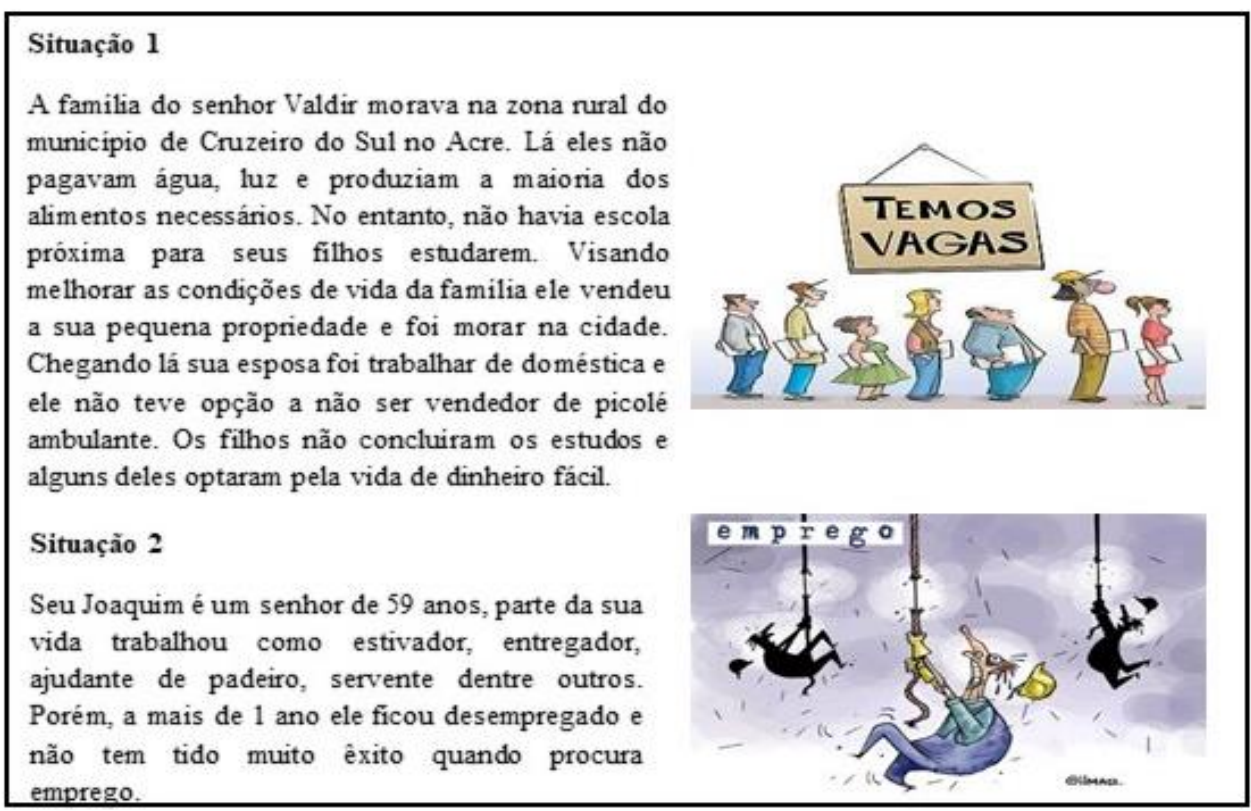

De maneira geral, os/as estudantes consideraram a falta de instrução o cerne da questão, pois sem conhecimento/estudo resta o trabalho de menor rentabilidade, ou as pessoas não são absorvidas pelo mercado de trabalho, vivendo, portanto, de trabalhos temporários. Algumas falas ilustram bem esse momento dialógico a respeito da situação analisada:

...professora é desse jeito mesmo, o que mais tem é gente sem trabalhar...eu não vou longe não...meu pai saiu do trabalho de entregador e depois disso não conseguiu mais nada certo (roda dialógica).

...Na cidade é mais complicado já que tudo precisa de dinheiro, então a vida é mais difícil de quem mora na colônia ...não dar para entender porque as pessoas vem para Rio Branco se aqui também não tá assim tão bom de trabalho... (roda dialógica). 
...Se não tem trabalho, mesmo pra quem estuda...imagina aí para quem não... (roda dialógica).

A questão do emprego/trabalho e falta de instrução volta a ser o centro das discussões, mencionando-se inclusive sobre o aumento da população na cidade, desemprego e pobreza, mas nenhuma relação de tais questões com relações capitalistas de produção, que no contexto do Acre é representado pela economia extrativista, na primeira fase de colonização, e pela agropecuária, mais recentemente.

\subsection{Validação dos temas geradores e construção dos contratemas}

Ao final da realização das atividades de problematização, via roda dialógica, analisaram-se as falas utilizando o quadro esquemático proposto por Silva (2004) (quadro 1), onde foram identificados os limites explicativos dos/das estudantes para cada questão, confirmando, assim, as falas em temas geradores. Com base nos elementos presentes na visão dos/das alunos/nas, definiram-se os contratemas que se referem à visão de mundo do educador sobre os temas geradores, os quais, de acordo com Silva, apontam para apreensão de conhecimentos que visam a superação dos limites explicativos dos/das estudantes acerca das questões/situações.

Quadro 1: Quadro de análise das falas significativas

\begin{tabular}{|c|c|c|c|c|}
\hline $\begin{array}{c}\text { Temas } \\
\text { Geradore } \\
\quad \mathbf{S}\end{array}$ & $\begin{array}{l}\text { Limite explicativo } \\
\text { (aluno) }\end{array}$ & $\begin{array}{c}\text { Elementos } \\
\text { presentes na } \\
\text { visão do aluno }\end{array}$ & $\begin{array}{l}\text { Visão de mundo do } \\
\text { educador } \\
\text { (Contratema) }\end{array}$ & $\begin{array}{c}\text { Elementos } \\
\text { presentes na } \\
\text { visão de mundo } \\
\text { do educador }\end{array}$ \\
\hline \multicolumn{5}{|c|}{ EDUCAÇÃO } \\
\hline Fala 1 & $\begin{array}{l}\text { A ignorância leva as } \\
\text { pessoas á } \\
\text { criminalidade. }\end{array}$ & $\begin{array}{l}\text { Educação, } \\
\text { conhecimento, } \\
\text { trabalho, } \\
\text { idoneidade. }\end{array}$ & $\begin{array}{l}\text { Educação elemento de } \\
\text { transformação social. }\end{array}$ & $\begin{array}{l}\text { Educação, } \\
\text { currículo } \\
\text { escolar, cultura, } \\
\text { trabalho, má } \\
\text { distribuição de } \\
\text { renda, sociedade } \\
\text { de classes. }\end{array}$ \\
\hline Fala 2 & $\begin{array}{lr}\text { Conduz } & \text { a } \\
\text { conscientização } & \text { do } \\
\text { valor da natureza. } & \end{array}$ & $\begin{array}{l}\text { Educação para } \\
\text { conscientizar, } \\
\text { preservar para } \\
\text { atender as } \\
\text { necessidades } \\
\text { humanas. }\end{array}$ & $\begin{array}{l}\text { Educação Ambiental é } \\
\text { meio para transformação } \\
\text { social. }\end{array}$ & $\begin{array}{l}\text { Currículo } \\
\text { escolar, } \\
\text { problematização } \\
\text { da realidade, } \\
\text { cultura, sistemas } \\
\text { políticos } \\
\text { econômicos. }\end{array}$ \\
\hline \multicolumn{5}{|c|}{$\begin{array}{l}\text { VIOLÊNCIA E CRIMINALIDADE } \\
\end{array}$} \\
\hline Fala 3 & $\begin{array}{lr}\text { Resolver } & \text { os } \\
\text { problemas } & \text { de } \\
\text { violência } & \mathrm{e} \\
\text { criminalidade } & \text { é } \\
\text { apenas questão } & \text { de } \\
\text { segurança pública. } & \end{array}$ & $\begin{array}{l}\text { Segurança, } \\
\text { violência, } \\
\text { convivência. }\end{array}$ & $\begin{array}{l}\text { Somente ações policiais } \\
\text { não são capazes de } \\
\text { conter a criminalidade. } \\
\text { São necessárias políticas } \\
\text { sociais que atuem na } \\
\text { base do problema. }\end{array}$ & $\begin{array}{l}\text { Educação, } \\
\text { política, } \\
\text { convivência, } \\
\text { legislação, } \\
\text { ocupação. }\end{array}$ \\
\hline Fala 4 & $\begin{array}{l}\text { Não denunciar os } \\
\text { autores dos crimes é } \\
\text { evitar represálias. }\end{array}$ & $\begin{array}{l}\text { Insegurança, } \\
\text { criminalidade, } \\
\text { naturalização da } \\
\text { violência. }\end{array}$ & $\begin{array}{l}\text { Criminalidade resultado } \\
\text { da concentração de } \\
\text { renda, que amplia a } \\
\text { pobreza e expõe a } \\
\text { população } \\
\text { vulnerável. }\end{array}$ & $\begin{array}{l}\text { Educação, } \\
\text { igualdade, } \\
\text { trabalho, renda e } \\
\text { Justiça Social. }\end{array}$ \\
\hline
\end{tabular}




\begin{tabular}{|c|c|c|c|c|}
\hline \multicolumn{5}{|c|}{ INFRAESTRUTURA/HABITAÇÃ̃/MEIO AMBIENTE } \\
\hline Fala 5 & $\begin{array}{l}\text { Reconhece a baixa } \\
\text { qualidade do serviço, } \\
\text { naturaliza o desvio } \\
\text { de recurso em obras } \\
\text { públicas. }\end{array}$ & $\begin{array}{l}\text { Baixo } \\
\text { investimento em } \\
\text { infraestrutura } \\
\text { em áreas } \\
\text { populares. } \\
\text { Desvio de } \\
\text { recursos } \\
\text { públicos. }\end{array}$ & \begin{tabular}{lr} 
Os investimentos & em \\
infraestrutura & são \\
incipientes e & não \\
atendem as necessidades \\
\multicolumn{2}{l}{ da população. }
\end{tabular} & $\begin{array}{l}\text { Infraestrutura, } \\
\text { política, ética. } \\
\text { Governança } \\
\text { para classes de } \\
\text { poder aquisitivo. }\end{array}$ \\
\hline Fala 6 & $\begin{array}{l}\text { Apenas indignam-se } \\
\text { quanto ao uso de } \\
\text { casas populares em } \\
\text { troca de favores } \\
\text { políticos sem alguma } \\
\text { manifestação. }\end{array}$ & $\begin{array}{lr}\text { Naturaliza } & \text { a } \\
\text { corrupção } & \\
\text { existente } & \text { nos } \\
\text { projetos } & \text { de } \\
\text { habitação. } & \end{array}$ & $\begin{array}{l}\text { A habitação de áreas } \\
\text { irregulares } \\
\text { associada ao está } \\
\text { rural. Políticas de } \\
\text { habitação ineficiente. }\end{array}$ & $\begin{array}{l}\text { Infraestrutura, } \\
\text { política, } \\
\text { compromisso } \\
\text { social. }\end{array}$ \\
\hline Fala 7 & $\begin{array}{lr}\text { A solução para os } \\
\text { córregos res que } \\
\text { recebem ras águas } \\
\text { servidas é escondê- } \\
\text { los para evitar o mau } \\
\text { cheiro. }\end{array}$ & $\begin{array}{l}\text { Infraestrutura } \\
\text { para esconder o } \\
\text { problema. }\end{array}$ & $\begin{array}{l}\text { Esconder os cursos de } \\
\text { água poluídos não é a } \\
\text { solução, mas sim criar } \\
\text { políticas de tratamento } \\
\text { dos efluentes antes deles } \\
\text { serem depositados nas } \\
\text { águas. }\end{array}$ & $\begin{array}{l}\text { Saúde, } \\
\text { infraestrutura, } \\
\text { educação, } \\
\text { política } \\
\text { cultura. }\end{array}$ \\
\hline \multicolumn{5}{|c|}{ EMPREGO E RENDA } \\
\hline Fala 8 & $\begin{array}{l}\text { A infelicidade está } \\
\text { associada a possuir } \\
\text { um objeto popular. }\end{array}$ & $\begin{array}{l}\text { Renda, trabalho, } \\
\text { desemprego. }\end{array}$ & $\begin{array}{l}\text { Desemprego; falta de } \\
\text { perspectiva de renda. }\end{array}$ & $\begin{array}{l}\text { Trabalho, } \\
\text { educação, } \\
\text { política, } \\
\text { distribuição de } \\
\text { renda. }\end{array}$ \\
\hline Fala 9 & $\begin{array}{lr}\text { O desemprego } & \text { e a } \\
\text { falta de renda } \\
\text { desqualificam } r o \\
\text { homem r como } \\
\text { provedor da família. }\end{array}$ & $\begin{array}{l}\text { Trabalho } \\
\text { convivência. }\end{array}$ & $\begin{array}{l}\text { Desemprego e a falta de } \\
\text { perspectiva de renda. }\end{array}$ & $\begin{array}{l}\text { Trabalho, } \\
\text { educação, } \\
\text { política, } \\
\text { distribuição de } \\
\text { renda. }\end{array}$ \\
\hline Fala 10 & $\begin{array}{l}\text { Redução de salário } \\
\text { justificado pela crise } \\
\text { do país. } \\
\text { Baixa expectativa de } \\
\text { renda. }\end{array}$ & $\begin{array}{l}\text { Educação, } \\
\text { renda, trabalho, } \\
\text { convivência. }\end{array}$ & $\begin{array}{l}\text { A crise não pode } \\
\text { justificar a redução do } \\
\text { salário e o serviço } \\
\text { continuar o mesmo. }\end{array}$ & $\begin{array}{l}\text { Educação, } \\
\text { justiça social, } \\
\text { dignidade. }\end{array}$ \\
\hline
\end{tabular}

\subsection{Organização da rede temática}

Validadas as falas em temas geradores e identificados os seus respectivos contratemas, organizou-se uma rede temática estruturada a partir do modelo de ocupação e desenvolvimento da Amazônia, imposto pelo capital estrangeiro que desencadeou efeitos negativos sobre a população e o meio ambiente, especialmente na sua porção Sul-Ocidental que abrange o estado do Acre e partes do Amazonas e Rondônia (figura 4). 
Figura 4: Rede Temática

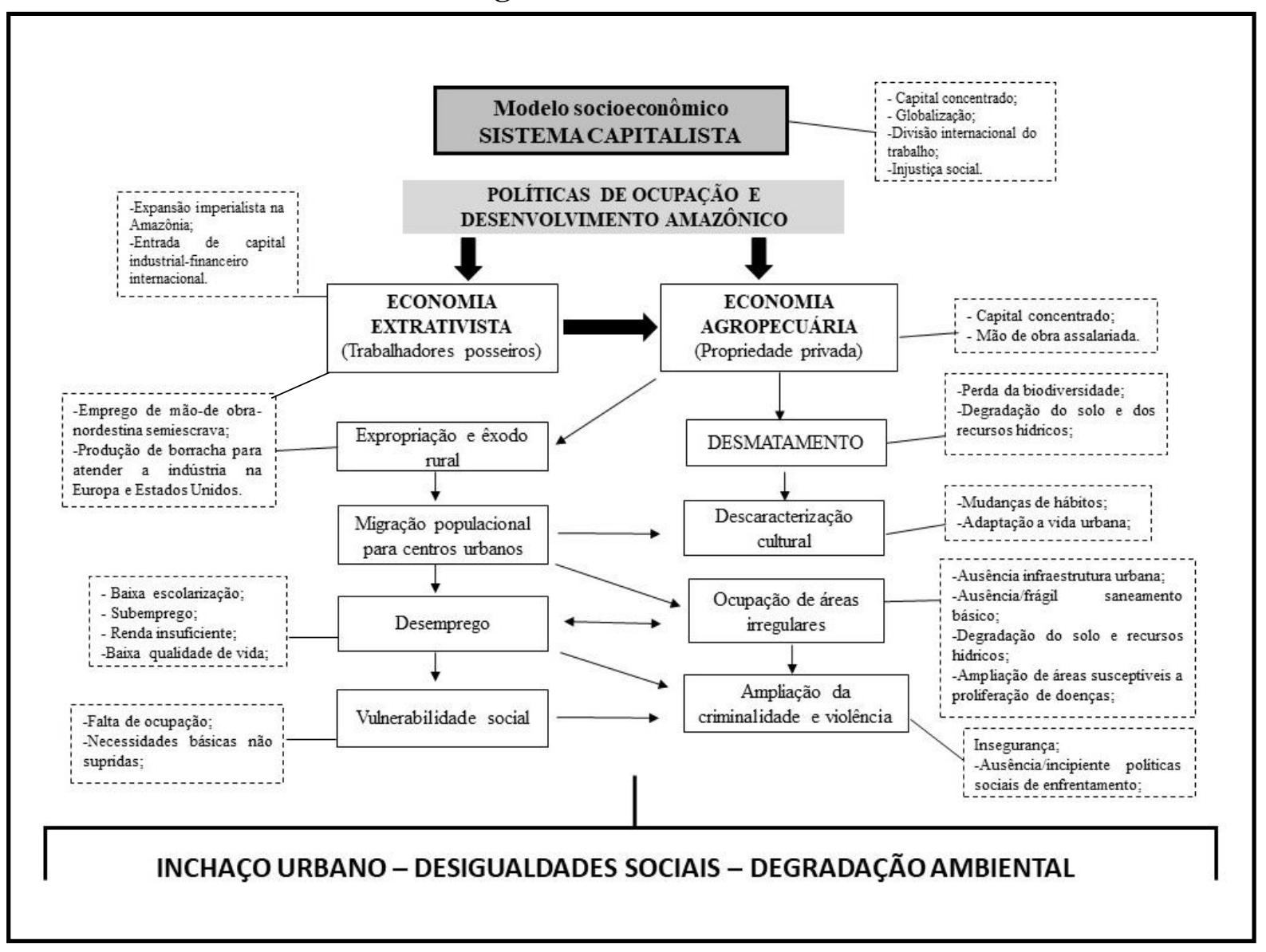

\subsection{Redução temática: organização dos conteúdos para abordagem ambiental via temas geradores}

Concluídas as etapas relacionadas ao processo investigativo de temas geradores, realizou-se a redução temática. Segundo Freire (2011), na realidade não escolar, após a delimitação temática, cabe a cada especialista, dentro do seu campo, apresentar o projeto de redução de seu tema. Como, no caso dessa pesquisa, a investigação temática foi uma iniciativa da professora-pesquisadora, a elaboração do programa de conteúdos foi feita, especificamente, no âmbito do ensino de geografia, porém sua aplicação envolveu conhecimentos de outras áreas das ciências humanas como história e sociologia e ciências biológicas, na composição dos núcleos fundamentais com vistas à inserção da temática ambiental.

Em virtude da quantidade de temas geradores, definiu-se uma questão geradora bastante ampla para redução dos temas: Que impactos os fatores geopolíticos, econômicos $e$ sociais têm sobre o desmatamento, as queimadas, as enchentes, a poluição hídrica, o incipiente saneamento básico, as questões de desigualdade e conflitos?. Abaixo consta o plano de conteúdos com respectivas estratégias para abordagem dos temas geradores, os quais integram a temática ambiental (quadro 2). 
Quadro 2: Programa de conteúdos para inserção da temática ambiental

\begin{tabular}{|c|c|c|}
\hline \multicolumn{3}{|c|}{ ABORDAGEM GLOBAL } \\
\hline Conteúdos & Recursos didáticos & $\begin{array}{l}\text { Intencionalidades } \\
\text { pedagógicas }\end{array}$ \\
\hline $\begin{array}{l}\text { Constituição e fases do } \\
\text { sistema capitalista; } \\
\text { Revolução Industrial; }\end{array}$ & Textos, slides, seminários. & $\begin{array}{lr}\text { Compreender a formação } \\
\text { do sistema } & \text { capitalista } \\
\text { como } & \text { elemento } \\
\text { determinante da } & \text { pirâmide } \\
\text { social. } & \end{array}$ \\
\hline 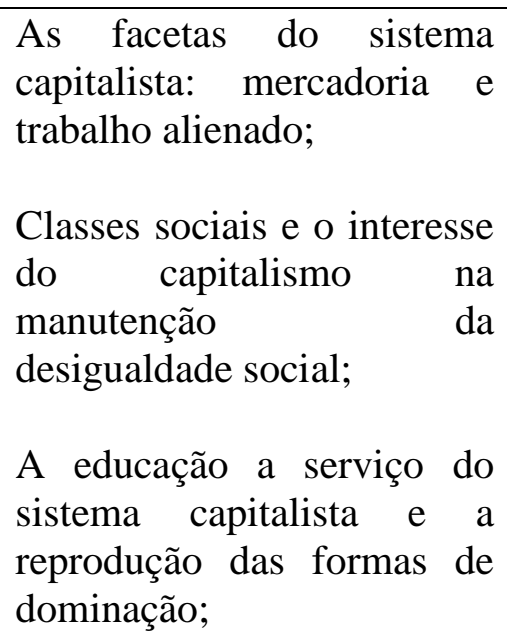 & $\begin{array}{l}\text { Filmes e Documentário: } \\
\text { 1) Tempos Modernos; } \\
\text { (https://www.youtube.com/wat } \\
\text { ch?v=ieJ1_5y7fT8); } \\
\text { 2) Curta metragem "El } \\
\text { Empleo"; } \\
\text { (https://www.youtube.com/wat } \\
\text { ch?v=cxUuU1jwMgM); } \\
\text { 3) "Carne e Osso"; } \\
\text { (https://www.youtube.com/wat } \\
\text { ch?v=_X8ALDZH_Dk); } \\
\text { 4) Atividade } \\
\text { problematização. }\end{array}$ & $\begin{array}{l}\text { Em virtude de tratar-se de } \\
\text { estudantes vinculados a } \\
\text { educação } \\
\text { profissionalizante buscou- } \\
\text { se discutir algumas } \\
\text { categorias vinculadas a } \\
\text { produção e ao trabalhador } \\
\text { no sistema capitalista. }\end{array}$ \\
\hline $\begin{array}{l}\text { A guerra fria e o mundo } \\
\text { bipolar; } \\
\text { Regionalização do mundo } \\
\text { (países do eixo sul e do eixo } \\
\text { norte); } \\
\text { Liberalismo econômico; } \\
\text { Globalização e suas } \\
\text { implicações econômicas, } \\
\text { sociais e ambientais; }\end{array}$ & $\begin{array}{l}\text { Textos variados/livro didático; } \\
\text { Atividades codificadas; } \\
\text { Produção de paródias. }\end{array}$ & $\begin{array}{l}\text { Aqui desenvolveu-se uma } \\
\text { abordagem acerca da } \\
\text { Guerra Fria e seus } \\
\text { desdobramentos para o } \\
\text { mundo moderno. Divisão } \\
\text { internacional do trabalho; } \\
\text { países detentores de } \\
\text { tecnologias, países } \\
\text { fornecedores de matéria } \\
\text { prima e mão de obra. }\end{array}$ \\
\hline $\begin{array}{l}\text { Sistema produtivo em } \\
\text { colapso; } \\
\text { Quem produz mais, quem } \\
\text { polui mais, quem vive } \\
\text { melhor no mundo??; }\end{array}$ & $\begin{array}{l}\text { Filme: } \\
\text { História das coisas, poluição e } \\
\text { degradação ambiental } \\
\text { (https://www.youtube.com/wat } \\
\text { ch?v=NrcNDeMSoHI); } \\
\text { Matéria jornalística: } \\
\text { Porque salvar as abelhas? } \\
\text { (Revista Veja). }\end{array}$ & $\begin{array}{l}\text { Buscou-se abordar quanto } \\
\text { a crise civilizatória pelo } \\
\text { qual o mundo passa em } \\
\text { função do modelo } \\
\text { produtivo que se encontra } \\
\text { em colapso. }\end{array}$ \\
\hline & RDAGEM REGIONAL E LOC & AL \\
\hline Conteúdos & \begin{tabular}{|l|} 
Recursos didáticos \\
\end{tabular} & Abordagem/finalidade \\
\hline $\begin{array}{lcc}\text { Política de ocupação } & \text { e } \\
\text { desenvolvimento para } & \text { a } \\
\text { Amazônia: integração ao } \\
\text { processo a }\end{array}$ & $\begin{array}{l}\text { Palestra com historiadora que } \\
\text { abordou o processo de } \\
\text { ocupação da Amazônia a partir } \\
\text { de preocupações com relação à } \\
\text { integridade nacional e } \\
\text { aproveitamento de seus } \\
\text { recursos para ampliação do }\end{array}$ & $\begin{array}{l}\text { Conhecer as intenções do } \\
\text { governo nacional quanto à } \\
\text { ocupação da Amazônia. }\end{array}$ \\
\hline
\end{tabular}




\begin{tabular}{|c|c|c|}
\hline & capital nacional. & \\
\hline $\begin{array}{l}\text { Produção de } \\
\text { natural: dinâmica producha } \\
\text { imposta pelo capital } \\
\text { internacional; } \\
\text { Mão de obra nordestina: } \\
\text { soldados de guerra ou da } \\
\text { borracha; }\end{array}$ & $\begin{array}{l}\text { Textos; } \\
\text { Visitação ao Museu do Xapuri. }\end{array}$ & $\begin{array}{l}\text { Compreender que a } \\
\text { produção da borracha } \\
\text { funcionava aos modos de } \\
\text { produção capitalista, } \\
\text { financiada pelo capital } \\
\text { estrangeiro (europeu e } \\
\text { norte-americano), } \\
\text { princípio para atender a } \\
\text { indústria pneumática e } \\
\text { posteriormente como } \\
\text { suprimento na } 2^{\text {a Guerra }} \\
\text { Mundial. }\end{array}$ \\
\hline $\begin{array}{l}\text { A falência dos Seringais da } \\
\text { Amazônia Sul-Ocidental e o } \\
\text { impacto na vida dos } \\
\text { trabalhadores rurais; } \\
\text { Expansão da fronteira } \\
\text { agropecuária no Acre; } \\
\text { Mudança no uso da terra: } \\
\text { desmatamento, degradação } \\
\text { do solo, impactos sobre a } \\
\text { diversidade biológica e } \\
\text { recursos hídricos; }\end{array}$ & $\begin{array}{l}\text { Estudo do Meio } \\
\text { 1) Observação da paisagem } \\
\text { agropecuária ao longo da BR } \\
364 \text { (antigas áreas de produção } \\
\text { de borracha); } \\
\text { 2) Visita a agroindústria de } \\
\text { produção de biocombustível } \\
\text { (álcool). }\end{array}$ & $\begin{array}{l}\text { Percepção das mudanças } \\
\text { socioculturais } \\
\text { socioambientais com a } \\
\text { economia extrativista e } \\
\text { expansão da fronteira } \\
\text { agrícola na porção da } \\
\text { Amazônia Sul-Ocidental. }\end{array}$ \\
\hline $\begin{array}{l}\text { Expropriação populacional: } \\
\text { Choques entre grupos } \\
\text { diversos em } \\
\text { sociocultural e espacial } \\
\text { diferentes: agropecuaristas, } \\
\text { camponeses, extrativistas, } \\
\text { índios; }\end{array}$ & $\begin{array}{l}\text { Atividades contextualizadas } \\
\text { via codificação (imagens) } \\
\text { Documentários: } \\
\text { "Chico Mendes vive"; } \\
\text { "Chico Mendes, o preço da } \\
\text { Floresta". } \\
\text { Visitas: } \\
\text { Centro de memória Chico } \\
\text { Mendes; } \\
\text { Fundação Chico Mendes. } \\
\text { Observação ao Rio Acre, umas } \\
\text { das principais vias para } \\
\text { escoamento da borracha, } \\
\text { atualmente bastante degradado. }\end{array}$ & $\begin{array}{l}\text { A nova política de } \\
\text { desenvolvimento regional, } \\
\text { com base em atividades } \\
\text { agropecuárias, gerou uma } \\
\text { série de conflitos por ter } \\
\text { desconsiderado os } \\
\text { trabalhadores extrativistas } \\
\text { e pequenos produtores } \\
\text { rurais. }\end{array}$ \\
\hline $\begin{array}{l}\text { Migrações campo-cidade: } \\
\text { Novas dinâmicas de } \\
\text { conflitos sociais; } \\
\text { Mudanças socioculturais no }\end{array}$ & $\begin{array}{l}\text { Atividades codificadas (uso de } \\
\text { imagens). } \\
\text { Resgate das situações } \\
\text { significativas. }\end{array}$ & $\begin{array}{l}\text { Buscou-se a relação entre } \\
\text { a população expropriada } \\
\text { do campo para cidade, } \\
\text { decorrente da nova } \\
\text { dinâmica produtiva, e os }\end{array}$ \\
\hline
\end{tabular}




\begin{tabular}{|c|c|c|}
\hline $\begin{array}{l}\text { espaço urbano; } \\
\text { Urbanização acelerada e } \\
\text { vulnerabilidade } \\
\text { socioambiental: } \\
\text {-Ocupação de áreas } \\
\text { irregulares/baixa } \\
\text { infraestrutura; } \\
\text {-Contaminação do solo e da } \\
\text { água com consequências à } \\
\text { saúde ambiental e humana; } \\
\text {-Incipientes postos de } \\
\text { trabalho; } \\
\text {-Baixa Renda; } \\
\text {-Territorialização } \\
\text { organização de atividades } \\
\text { ilícitas; } \\
\text {-Ampliação } \\
\text { criminalidade e violência; }\end{array}$ & & $\begin{array}{l}\text { conflitos, contradições e } \\
\text { desigualdades sociais que } \\
\text { se estabelecem nos } \\
\text { ambientes urbanos, os } \\
\text { quais reproduzem-se pela } \\
\text { ausência de políticas } \\
\text { públicas para o } \\
\text { enfretamento e solução. }\end{array}$ \\
\hline $\begin{array}{l}\text { O papel dos movimentos } \\
\text { sociais na luta e resistência } \\
\text { contra as forças capitalistas; } \\
\text { "Empates": símbolo de luta } \\
\text { e resistência pela posse da } \\
\text { terra e manutenção dos } \\
\text { modos de vidas tradicionais; }\end{array}$ & $\begin{array}{l}\text { Estudo do Meio: } \\
\text { Comunidade rural do "Seringal } \\
\text { Cachoeira". } \\
\text { (Trata-se de uma das } \\
\text { comunidades acreanas que } \\
\text { resistiu à pressão dos } \\
\text { agropecuaristas e obteve o } \\
\text { direito pela terra). }\end{array}$ & $\begin{array}{l}\text { Compreender, via relatos } \\
\text { de membros da } \\
\text { comunidade, o processo de } \\
\text { luta e resistência dos } \\
\text { trabalhadores rurais na } \\
\text { década de } 80 \text {, quanto aos } \\
\text { conflitos enfrentados com } \\
\text { pecuaristas sulistas pela } \\
\text { posse da terra. }\end{array}$ \\
\hline
\end{tabular}

A primeira parte do programa, a qual denominamos abordagem global, propõe o diálogo a partir da análise da macro organização sociocultural e econômica. Para tanto, discorre-se sobre a formação do sistema capitalista como elemento determinante na regionalização do mundo e na pirâmide social, na organização do trabalho assim como seus efeitos negativos sobre o meio ambiente.

Posteriormente, é proposta uma abordagem regional e local onde apresenta-se uma análise socioeconômica regional tendo como base as políticas governamentais de povoamento para a região Amazônica, com destaque para a porção Sul-Ocidental, onde localiza-se o Acre, parte dos estados do Amazonas e Rondônia, as quais tiveram como força motora a exploração da borracha natural ocorrida em dois ciclos. Tanto o $1^{\circ}$ ciclo (1879 a 1912), que visava atender a indústria pneumática, quanto o $2^{\circ}$ ciclo (1942 a 1945), que ocorreu ocasionalmente durante a II Guerra Mundial para fins de suprir a produção de arsenais bélicos, motivou o deslocamento de inúmeros trabalhadores nordestinos para a região, que passaram a ocupar os seringais ao longo dos altos rios amazônicos (ESTEVES, 2010; SECRETO, 2007). Dá-se importante ênfase à organização da produção, a qual funcionava sobre os modos fiéis do sistema capitalista, conforme pode ser visualizado na figura 5 . 
Figura 5: Sistema produtivo e comercial da borracha na Amazônia

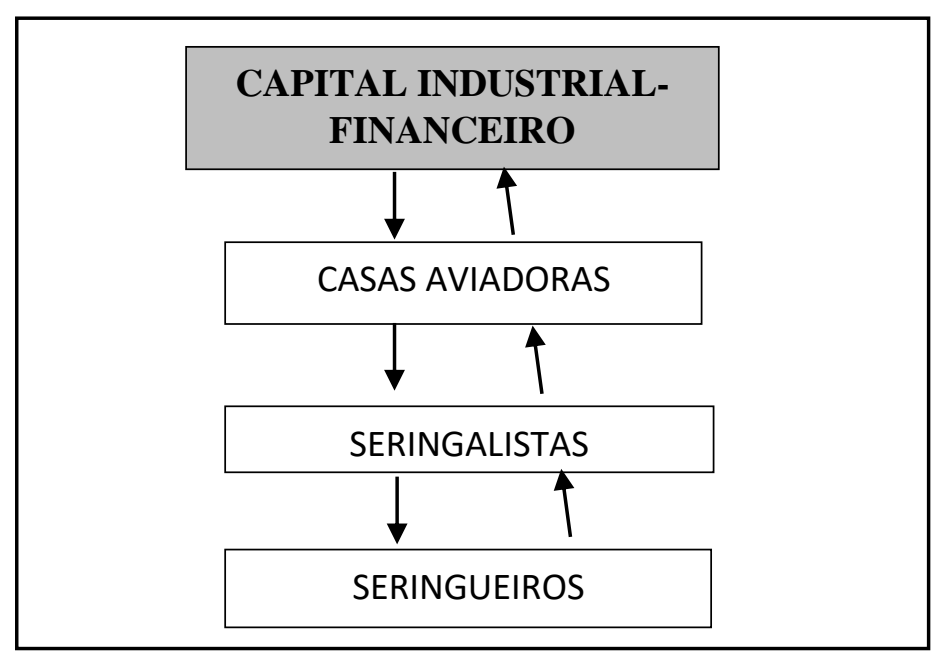

Fonte: Calixto, Souza e Souza (1985)

Conforme Calixto, Souza e Souza (1985), a organização da produção caracterizava-se por um sistema de encadeamento e dependência. Assim no extremo superior da figura 5 observa-se o capital industrial-financeiro internacional e as casas aviadoras correspondentes às matrizes internacionais, atuando no abastecimento dos seringais e comercialização da produção com o exterior. No extremo inferior da figura, encontra-se o produtor direto (seringueiros), a força de trabalho base do sistema, nesse caso mão de obra nordestina, população pobre que se deslocou, sem opção, de seus territórios de origem os quais passaram a compor a estrutura de produção de borracha natural.

Na sequência, ainda na abordagem regional e local os conteúdos elencados apresentam os desdobramentos socioambientais da falência do negócio da borracha com o encerramento da II Guerra Mundial, quebrando a estrutura de produção da borracha da Amazônia. Seringais são abandonados e os trabalhadores permanecem na condição de posseiros, sujeitos à própria sorte em meio à floresta. Os governos federal e estadual, já nas décadas de 60 e 70 desconsiderando esses trabalhadores, buscam uma segunda tentativa de ocupação da região, atraindo novos investidores, especialmente para o estado do Acre, alegando que na região havia imensas terras negociáveis a baixos preços (SILVA, 2003).

Segundo Silva (2003), essa nova frente de ocupação envolveu a criação de Projetos de Colonização, especialmente para assentar expropriados da modernização da agricultura do Centro-sul do país, bem como mobilizou empresários do ramo agropecuário da mesma região para adquirirem terras que perfaziam os antigos seringais, desencadeando uma série de conflitos com os ocupantes, incluindo a população nativa e seringueiros que, após a retirada da estrutura produtiva da borracha, continuaram vivendo de atividades extrativistas em menor escala e agricultura de subsistência. Os novos donos e o governo em nada foram complacentes com essa população e a nova atividade econômica passou a gerar impactos de diferentes dimensões e proporções. A expropriação da população decorrida da implantação e expansão dessa nova modalidade de ocupação desencadeou processos de êxodo rural, levando inúmeras famílias a migrarem para os núcleos urbanos, obrigando-se a abandonar seus modos de vida e a buscarem outras formas de sobrevivência, o que inclui ocupar as áreas periféricas ou inapropriadas das cidades, passando a viver em condições precárias de moradia e dificuldades de atendimento às necessidades básicas, em função do desemprego e da baixa renda (ACRE, 2010). 
$\mathrm{Na}$ ausência de políticas de enfrentamento para tal situação, que inicia com a exclusão da população rural, desencadeou-se nas décadas seguintes uma série de problemas nos centros urbanos, uma vez que não estavam preparados para o fenômeno mobilidade campo-cidade, conforme citado por documento produzido no âmbito do Programa Estadual de Zoneamento Ecológico-Econômico do Acre:

...À medida que o excedente de mão de obra ia sendo dispensado das áreas rurais, um contingente de desempregados se formava nos bairros e entornos de cidades acreanas ainda despreparadas para recebê-los (ACRE, 2010, p. 29).

Esses novos problemas acompanharam a formação do território acreano e refletem-se no contexto social dos/das estudantes, aliado às novas formas de reprodução dos modos de produção do capital, cada vez mais excludente e gerador de desigualdades e tensões sociais.

A apropriação pela nova forma de explorar a região gerou passivos ambientais com a exploração das madeiras de lei e a retirada da cobertura completa de vastas porções de terra para formação de pastagens e desenvolvimento das atividades agropecuárias (ACRE, 2010). Enquanto a economia girou em torno da produção da borracha, embora altamente exploradora e opressora, mantinham-se as condições naturais do ecossistema florestal. Já nesse novo momento, além da população ter seus modos de vida alterados, o novo uso da terra gerou impactos ao meio ambiente, a exemplo da degradação do solo, dos recursos hídricos e perda da biodiversidade, impactos esses que se estendem ao ambiente urbano desprovido de infraestrutura e saneamento básico.

Esse desdobramento histórico remete-se ao posicionamento de Loureiro e seus colaboradores (2009), os quais enfatizam estarmos vivendo o avanço do capital, ao tempo que se ampliam as riquezas, no mesmo movimento, também cresce a pobreza e consequentemente a degradação ambiental. Nesse compasso, "esvaziam-se também as instituições públicas e uso do Estado como elemento que legitima e reproduz a acumulação via liberalização de mercado" (LOUREIRO, 2009, p.03).

Complementarmente, Costa e Loureiro (2015) nos permitem ampliar tais reflexões, quanto às políticas de povoamento da Amazônia, que culminaram com a exploração de recursos naturais, da mão de obra de imigrantes nordestinos e a expansão da fronteira agrícola, visando principalmente atender a interesses capitalistas em detrimento às questões de ordem social:

\begin{abstract}
O desenvolvimento do capitalismo expõe desde o seu princípio, que o processo de acumulação impôs a necessidade de expandir fronteiras a todas as regiões do mundo para a exploração de seus recursos, assim como a força de trabalho. Tal processo começa a configurar-se na fase de desenvolvimento mercantil. Nesse período, o capital conseguiu mercantilizar os minerais, os vegetais, os animais e o espaço natural (COSTA e LOUREIRO, 2015, p. 08).
\end{abstract}

Os autores acima apresentam os objetivos do capitalismo, os quais podem ser transpostos para a discussão deste artigo no que se refere à expansão da fronteira desenvolvimentista no sentido Amazônica Sul-Ocidental, objetivos que serviram de base para a estruturação da rede temática (figura 4).

Por último, elenca-se no plano de conteúdos, em meio a esse processo histórico de formação do espaço acreano, o movimento de luta e resistência organizado por trabalhadores rurais, sob a liderança de Chico Mendes (década de 1970), frente à expansão da agropecuária. Apesar de vidas terem sido ceifadas nessa trajetória, a exemplo de lideranças sindicais, o movimento dos trabalhadores rurais foi fundamental e forçou os governantes a ceder pela garantia de que uma parcela da população rural permanecesse em suas terras. Isso foi possível graças à criação das reservas extrativistas, modalidade de reforma agrária para povos tradicionais da floresta. 
Para melhor compreender o papel do movimento de resistência na região, propôs-se nesta pesquisa, um estudo do meio onde os/as estudantes foram encaminhados a um seringal em funcionamento (quando da execução do plano), que atualmente atende à indústria de preservativos masculinos com demanda do Ministério da Saúde. A atividade iniciou-se com a observação da paisagem agropecuária, que antes era constituída por áreas produtivas de borracha, até a chegada a uma comunidade rural símbolo da resistência de conflitos entre trabalhadores rurais e agropecuaristas. Trata-se de uma minoria que resistiu à expropriação rural, mantendo os modos de vida tradicionais vinculados ao extrativismo, a agricultura de subsistência e o turismo ecológico.

Os temas geradores obtidos, que refletem o contexto dos/das estudantes, mas que possivelmente fez parte da história dos seus avós e bisavós possibilitaram a integração das questões sociais com as ambientais, as quais carregam a marca da opressão e dominação, fruto do modelo de ocupação e das políticas de desenvolvimento para a região, centradas na injustiça social e a favor da estrutura capitalista de produção. Enquanto possibilidade metodológica na educação ambiental crítico-transformadora, os temas operaram como ponto de partida para o processo da práxis crítica ao possibilitar a organização de currículo que dialoga com os contextos socioambientais dos/das estudantes, na conjectura do modelo capitalista de produção.

O plano de conteúdos, organizado via dinâmica de abordagem temática freiriana, utilizando-se do contexto histórico, vinculado às políticas de ocupação e desenvolvimento para a Amazônia, dialoga com as ideias de Layrargues (2009) ao citar que:

...no campo da educação ambiental, trabalhar com processos pedagógicos vinculados à expansão da fronteira desenvolvimentista com os grupos sociais em condições de risco e vulnerabilidade ambiental permite a abordagem contextualizada, complexa e crítica (LAYRARGUES, 2009, p. 27).

\section{Considerações finais}

Considerando as perguntas de investigação, os dados da pesquisa mostraram que, através da abordagem temática freiriana, é possível inserir a dimensão ambiental no ensino médio profissionalizante em uma perspectiva crítico-transformadora, uma vez que os temas geradores possibilitaram a abordagem das questões ambientais integradas aos aspectos políticos, econômicos, culturais e históricos, os quais se entrelaçam com as condições sociais em que estão inseridos os/as estudantes.

O processo de investigação e redução temática culminou com a efetivação de vários atributos da educação ambiental, presentes nos documentos legais, em uma perspectiva crítico-transformadora, o que já havia sido conjecturado por Torres (2010); Torres e Maestrelli (2013) e Müller e Torres (2015). Tais atributos encontram-se materializados no plano de conteúdos e sua proposta de execução, em que são consideradas as visões de mundo dos/das estudantes, condicionantes para superar os limites explicativos quanto às situações que caracterizam seus contextos socioambientais, assim como o entendimento de educação e trabalho como condicionadores de libertação individual e não de transformação social.

Destacamos que a participação dos familiares na construção temática foi um ponto positivo na investigação de temas geradores, pois desvelou com maior número de detalhes as situações significativas, permitindo, assim, melhor problematização e contextualização. Outro aspecto positivo da abordagem temática, nesta pesquisa, foi a adoção de diversos outros recursos pedagógicos, além do livro didático, já que este de, forma geral, não oportuniza a abordagem com base no contexto local.

Podemos afirmar que a educação ambiental, via abordagem temática freiriana, foge à rotina do educador convencional ou conservador, implicando aprofundamento teórico, onde é possível conhecer a realidade dos educandos (situações socioambientais), num processo de sistematização, reflexão e ação. 


\section{Referências}

ACRE, Secretaria de Estado de Meio Ambiente. Cultural político: memórias, identidades e territorialidades. ZEE/AC, fase II, escala 1: 250.000/Programa Estadual de Zoneamento EcológicoEconômico do Acre. Rio Branco: [ s.n.], 2010.

CALIXTO, V.O.; SOUZA, J.F.; SOUZA, J.D. Acre: uma história em construção. Rio Branco: Impresso no Brasil/Printed in Brasil, 1985. 223 p.

CARVALHO, I.C.M. Transformações na esfera pública e ecologia: educação e política em tempos de crise da modernidade. In: COSTA, C. A. S. e LOUREIRO, C. F. B. (Org.). A questão ambiental: interfaces críticas. 1ed. Curitiba: Appris Editora e Livraria Ltda-ME, 2013, v. 1, p. 109-122.

COSTA, C.A.; LOUREIRO, C.F. Interculturalidade, exclusão, e libertação em Paulo Freire na leitura de Enrique Dussel: aproximações para a pesquisa em educação ambiental crítica. In: Encontro Pesquisa em Educação Ambiental, 8., Anais..., Rio de Janeiro, 2015. Disponível em: http://epea.tmp.br/epea2015_anais/pdfs/plenary/3.pdf. Acessado em: 04 de março de 2017.

DELIZOICOV, D. Concepção problematizadora do ensino de ciências na educação formal. 1982. Dissertação (Mestrado em Educação). Faculdade de Educação, Universidade de São Paulo, São Paulo, 1982.

. La Educación en Ciencias y la Perspectiva de Paulo Freire. In: ALEXANDRIA Revista de Educação em Ciência e Tecnologia, v.1, n.2, p.37-62, jul. 2008. Disponível em: <http://www.ppgect.ufsc.br/alexandriarevista/numero_2/artigos/demetrio.pdf.>. Acessado em: 20 fev. 2017.

; ANGOTTI, J. A. P.; PERNAMBUCO, M. M. C. A. Ensino de Ciências: Fundamentos e Métodos. São Paulo: Cortez, 2011.

DEMARTINI, G.R.; SILVA, A.F.G. Abordagem temática na sistematização curricular para o desenvolvimento de ciências: gravidez na adolescência em uma escola estadual do município de Sorocaba. In: Encontro de Pesquisas em Educação em Ciências, 9.,Anais..., Águas de Lindóia-SP, 2013. P. 1-8. Disponível em: http://www.nutes.ufrj.br/abrapec/ixenpec/atas/resumos/R1039-1.pdf. Acessado em: 20 de maio de 2017.

ESTEVES, B.M.G. Do "manso" ao Guardião da floresta. Rio Branco: EDUFAC, 2010.

FREIRE, P. Pedagogia do oprimido. 50 ed. rev. e atual. Rio de Janeiro: Paz e Terra, 2011.

FREITAS, R. G. A.; PANZERI, C.G.; MEIRELLES, R. M. S. Marco Inicial da Educação Ambiental no Instituto Federal de Educação, Ciência e Tecnologia do Acre (IFAC). In: Encontro Nacional de Pesquisa em Educação em Ciências, 10., Anais...,Águas de Lindóia, 2015. P.1-8. Disponível em: http://www.abrapecnet.org.br/enpec/x-enpec/anais2015/resumos/R0795-1.PDF. Acessado em: 23 de agosto de 2017.

LAYRARGUES, P.P. 2014. A dimensão freireana na Educação Ambiental. In: LOUREIRO, C.F. B.; TORRES, J.R. (Orgs) Educação Ambiental: dialogando com Paulo Freire. São Paulo: Cortez, 2014. $184 \mathrm{p}$.

LAYRARGUES, P.P. A resolução de problemas ambientais locais deve ser um tema gerador ou atividade-fim da Educação Ambiental? In: REIGOTA, M. (Org.). Verde Cotidiano: o meio ambiente em discussão. Rio de Janeiro: DP\&A. 1999. p. 131-148.

Educação ambiental com compromisso social: o desafio da superação das desigualdades. LOUREIRO, C. F. B.; LAYRARGUES, P. P.; CASTRO, R. S.; BARBOSA, G.L.; QUINTAS, J.S.; ZBOROWSKI, M.B.; ZACARIAS, R.; MOLON, S.I. (Orgs). Repensar a Educação Ambiental. São Paulo: Cortez, 2009. 206 p.

LORENZETTI, L. DELIZOICOV, D. Estilos de pensamento em Educação Ambiental: uma análise a partir das dissertações e teses. In: Encontro Nacional de Pesquisa em Ensino de Ciências, 7., Anais..., 
Florianópolis, 2009. Disponível em: http://posgrad.fae.ufmg.br/posgrad/viienpec/pdfs/363.pdf. Acessado em: 25 de maio de 2017.

LOUREIRO, C.F.B. Trajetórias e Fundamentos da Educação Ambiental. São Paulo. Cortez. 2004.

; COSSÍO, M.F.B. Um olhar sobre a Educação Ambiental nas escolas: considerações iniciais sobre os resultados do projeto "O que fazem as Escolas que dizem que fazem Educação. IN: MEC/MMA. Vamos cuidar do Brasil: conceitos e práticas em educação ambiental na escola. Brasília, 2007.

; TREIN, E.; TOZONI-REIS, M.F.C.; NOVICKI, V. Contribuições da teoria marxista para a educação ambiental crítica. In: Cadernos Cedes, Campinas, v. 29, n. 77, jan./abr. 2009. Disponível em: http://www.scielo.br/pdf/ccedes/v29n77/a06v2977.pdf. Acessado em: outubro de 2017.

MULLER, L.; TORRES, J.R. A investigação de temas geradores para a inserção da dimensão ambiental crítico-transformadora na educação escolar. In: Encontro de Pesquisa em Educação Ambiental, 8., Anais..., Rio de Janeiro, 2015. Disponível em: http://epea.tmp.br/epea2015_anais/pdfs/plenary/116.pdf. Acessado em: 20 de dezembro de 2016.

PACHECO, E. (Org.). Perspectivas de Educação Profissional Técnica de Nível Médio: proposta de diretrizes curriculares nacionais. São Paulo: Moderna, 2012.

RINK, J.; LONGATTI, C.A.; DIAS, C.M. Educação Ambiental na Educação Profissional Técnica de Nível Médio: um Breve Panorama das Dissertações e Teses Brasileiras (1987-2009). In: BATISTA, S. S. S.; FREIRE, E. Educação Profissional Tecnológica: Perspectivas e experiências. Jundiá, Paco Editorial: 2015.

SECRETO, M.V. Soldados da borracha: trabalhadores entre o sertão e a Amazônia no governo Vargas. São Paulo. Editora Fundação Perseu Abramo, 2007.

SILVA, A.F.G. A construção do currículo na perspectiva popular crítica: das falas significativas às práticas contextualizadas. 2004. 405 f. Tese (Doutorado) - Programa de Pós Graduação em Educação - Currículo. Pontifícia Universidade Católica. São Paulo, 2004.

SILVA, S.S. Na fronteira agropecuária acreana. Rio Branco: [ s.n.], 2003. 229 p.

THIOLLENTT, M. Metodologia da Pesquisa Ação. São Paulo: Cortex, 2011.

TORRES, J.R. Educação Ambiental crítico-transformadora e abordagem temática freireana. Tese (Doutorado) - Programa em Educação Científica e Tecnológica, Centro de Ciências Biológicas: Universidade Federal de Santa Catarina, 2010.

; MAESTRELLI, S.R.P. Atributos da educação ambiental escolar no contexto educacional brasileiro: do movimento ambientalista internacional ao nacional. Revista Eletrônica do Mestrado em Educação Ambiental. v. 28. p. 115-132, 2012. Disponível em: https://www.seer.furg.br/remea/article/view/3109. Acessado em: 20 de setembro de 2017.

; DELIZOICOV, D. Os pressupostos da concepção educacional de Paulo Freire na pesquisa em educação ambiental no contexto formal: 12 anos de ENPEC. In: Encontro Nacional de Pesquisas em Educação em Ciências, 7., Anais..., Florianópolis, 2009. Disponível em: http://posgrad.fae.ufmg.br/posgrad/viienpec/pdfs/832.pdf. Acessado em: 30 de julho de 2017.

TOZONI-REIS, M.F.C. Temas ambientais como "temas geradores": contribuições para uma metodologia educativa ambiental crítica, transformadora e emancipatória. Revista Educar, Curitiba, n. 27, p. 93-110, 2006. Disponível em: http://www.scielo.br/scielo.php?script=sci_arttext\&pid=S010440602006000100007. Acessado em: 20 de maio de 2017.

; CAMPOS, L.M.L. A formação inicial de professores no fortalecimento da educação ambiental escolar: contribuições da pedagogia histórico crítica. In: LOUREIRO, C.F.B.; LAMOSA, R.A. (Orgs). Educação Ambiental no contexto escolar: Um balanço crítico da década da educação para o desenvolvimento sustentável. Rio de Janeiro: Quarter: CNPQ, 2015. 
; TALAMONI. J.L.B.; RUIZ, S.S.; NEVES, J. P.; TEIXEIRA, L.A; CASSINI, L.F.; FESTOZO, M.B.; JANKE, N.; MAIA, J.S.S.; SANTOS, H.M.S.; CRUZ, L. G.; MUNHOZ, R.H. A educação ambiental na escola básica: diretrizes para a divulgação dos conhecimentos científicos. Revista Pesquisa em Educação Ambiental, vol. 7, n. 1 - pp. 29-48, 2012. Disponível em: http://www.revistas.usp.br/pea/article/view/55941. Acessado em: 10 de novembro de 2016.

VEIGA, A.; AMORIM, E.; BLANCO, M. Um retrato da presença da educação ambiental no ensino fundamental brasileiro: o percurso de um processo acelerado de expansão. Brasília: INEP, 2005. 25 p. (Série Documental). 